University of Nebraska - Lincoln

DigitalCommons@University of Nebraska - Lincoln

May 1981

\title{
EFFECT OF MATERNAL DIETARY ENERGY SOURCE ON GLUCOSE HOMEOSTASIS, LIVER GLYCOGEN AND CARCASS LIPID IN THE NEONATAL PIG
}

\author{
R. D. Boyd \\ University of Nebraska-Lincoln \\ B. D. Moser \\ University of Nebraska-Lincoln
}

A. J. Lewis

University of Nebraska-Lincoln, alewis2@unl.edu

E. R. Peo Jr.

University of Nebraska-Lincoln

R. K. Johnson

University of Nebraska-Lincoln, rjohnson5@unl.edu

See next page for additional authors

Follow this and additional works at: https://digitalcommons.unl.edu/animalscifacpub

Part of the Animal Sciences Commons

Boyd, R. D.; Moser, B. D.; Lewis, A. J.; Peo, E. R. Jr.; Johnson, R. K.; and Nimmo, R. D., "EFFECT OF MATERNAL DIETARY ENERGY SOURCE ON GLUCOSE HOMEOSTASIS, LIVER GLYCOGEN AND CARCASS

LIPID IN THE NEONATAL PIG" (1981). Faculty Papers and Publications in Animal Science. 21.

https://digitalcommons.unl.edu/animalscifacpub/21

This Article is brought to you for free and open access by the Animal Science Department at DigitalCommons@University of Nebraska - Lincoln. It has been accepted for inclusion in Faculty Papers and Publications in Animal Science by an authorized administrator of DigitalCommons@University of Nebraska - Lincoln. 


\section{Authors}

R. D. Boyd, B. D. Moser, A. J. Lewis, E. R. Peo Jr., R. K. Johnson, and R. D. Nimmo 


\title{
EFFECT OF MATERNAL DIETARY ENERGY SOURCE ON GLUCOSE HOMEOSTASIS, LIVER GLYCOGEN AND CARCASS LIPID IN THE NEONATAL PIG ${ }^{1,2}$
}

\author{
R. D. Boyd ${ }^{3}$, B. D. Moser, A. J. Lewis, E. R. Peo, Jr., ${ }^{4}$ \\ R. K. Johnson and R. D. Nimmo \\ University of Nebraska, Lincoln 68583
}

\begin{abstract}
Summary
Two experiments were conducted to determine the effects of supplementary dietary energy (carbohydrate versus fat) fed to sows during late gestation on energy storage and glucose homeostasis in neonatal pigs. In the first experiment, 28 crossbred sows received one of two dietary treatments that were initiated on day 100 of gestation. The control group was fed daily $1.82 \mathrm{~kg}$ of a corn-soybean meal-based diet plus an additional $.18 \mathrm{~kg}$ of cornstarch. Their counterparts were fed $1.82 \mathrm{~kg}$ of a cornsoybean meal diet containing $8 \%$ bleachable fancy tallow. The effect of maternal dietary energy source during late gestation on glucose homeostasis was evaluated by fasting pigs from birth $\left(t_{0}\right)$, whereas the gestation-lactation effect was evaluated by fasting pigs after they had nursed the sow for $24 \mathrm{hr}\left(t_{24}\right)$. Pigs on the tallow treatment responded differently to the $t_{0}$ fast, as determined by the patterns of plasma glucose (treatment $x$ time, $P<.05$ ) and free fatty acids (treatment $x$ time, $P<.10$ ). The tallow group maintained a slightly higher glucose concentration during the initial $24 \mathrm{hr}$, after which no difference was observed. Control pigs reached a peak free farty acid (FFA) concentration by $12 \mathrm{hr}$, whereas the tallow
\end{abstract}

\footnotetext{
${ }^{1}$ Published as Paper No. 6052, Journal Ser., Nebraska Agr. Exp. Sta.

${ }^{2}$ Dept. of Anim. Sci. The authors wish to express appreciation to the Fats and Proteins Research Foundation, Des Plaines, IL, for partial financial support of this project.

${ }^{3}$ Present address: Dept. of Anim. Sci., Cornell Univ., Ithaca, NY.

${ }^{4}$ Person to whom reprint requests should be directed.
}

group reached a maximum by $24 \mathrm{hr}$, which corresponded with declining glucose concentration. Pigs on the $t_{24}$ tallow treatment maintained a slightly higher plasma glucose concentration during the initial $24 \mathrm{hr}$ of fasting (12 $\mathrm{hr}-68.3$ vs $63.2 \mathrm{mg} / 100 \mathrm{ml} ; 24 \mathrm{hr}-67.1$ vs $56.3 \mathrm{mg} / 100 \mathrm{ml}$ ); however, no significant treatment effect or treatment $x$ time interaction was observed. Pigs on the tallow treatment maintained a higher, although not significantly different, plasma FFA concentration during the fast (144 $\mu \mathrm{eq} / \mathrm{liter})$ than pigs in the control group (126 $\mu \mathrm{eq} / \mathrm{liter})$. In the second experiment, progeny of 12 sows were sacrificed immediately after birth. The respective carcass lipid (percentage) and liver glycogen (milligrams/gram) concentrations for pigs from sows fed the control and tallow diets were 1.48 , 229.1 vs $1.50,234.9$. The liver glycogen to body weight ratio (milligrams:gram) was 7.1 and 7.8 for the control and tallow groups, respectively.

(Key Words: Neonatal Pig, Glucose, Free Fatty Acids, Urea Nitrogen, Glycogen, Lipid.)

\section{Introduction}

Newborn pigs encounter several challenges to their survival during the initial hours of life (Mersmann, 1971). One is the inherent problem associated with glucose homeostasis, with the first day of life being the most critical period (Graham et al., 1941; Sampson et al., 1942; Swiatek et al, 1968; Gentz et al., 1970; Mersmann, 1974). Liver glycogen is rapidly depleted postnatally (12 to $24 \mathrm{hr}$ ) for the maintenance of blood glucose (Anderson and Wahlstrom, 1970; Hakkarainen, 1975; Elliot and Lodge, 
1977; Boyd et al., 1978a). In addition, there is little lipid stored for utilization and the pig's capacity for gluconeogenesis is largely underdeveloped (Swiatek et al., 1968; Swiatek, 1971; Mersmann, 1974). Therefore, maintenance of the physiologically critical energy metabolite, glucose, depends largely on the neonate's ability to compete with littermates for regular nourishment from its dam.

Efforts to increase the amount of energy stored in the pig at birth, by the addition of various lipid sources to the diet of the dam during late gestation, have resulted in little if any increase in carcass lipid (Seerley et al., 1974, 1978a,b; Friend, 1974; Okai et al., 1977; Boyd et al., 1978a). The effect on fetal liver glycogen storage and persistence during the initial postnatal hours remains unclear. However, smaller, less competitive pigs nursing sows fed a diet supplemented with tallow during late gestation and lactation maintained a higher concentration of plasma glucose during the initial $24 \mathrm{hr}$ after birth (Boyd et al., 1978a). The most evident result of lipid addition is an increase in the fat content of colostrum and milk.
The purpose of this study was to determine the effects of supplemental dietary energy (carbohydrate versus far) fed to sows during late gestation on liver glycogen content of pigs at birth and on glucose homeostasis when the pigs were fasted at birth or after $24 \mathrm{hr}$ of nursing. The plasma patterns of glucose, free fatty acids (FFA) and urea $N$ (UN) were used as response criteria. UN data were used to characterize the pattern of this constiruent in relation to glucose and FFA because $U N$ has received only limited research attention (Bengtsson, 1970). Liver glycogen and carcass lipid content of pigs at birth and colostrum fat and solids during the initial $24 \mathrm{hr}$ were determined for comparison with metabolite patterns.

\section{Experimental Procedure}

Exp. 1. Twenty-eight crossbred (Landrace $x$ Hampshire $\times$ Yorkshire $\times$ Duroc), third and fourth parity sows were used. All sows were fed $1.82 \mathrm{~kg}$ daily of a corn-soybean meal diet (14\% protein) fortified with vitamins and minerals until day 100 of gestation. Subsequently, sows were placed in farrowing crates and assigned to either of two dietary treatments (table 1). The

TABLE 1. DIET COMPOSITION AND REGIMEN

\begin{tabular}{|c|c|c|}
\hline \multirow[b]{2}{*}{ Ingredient, \% } & \multicolumn{2}{|c|}{ Tallow, \% } \\
\hline & 0 & 8 \\
\hline $\begin{array}{l}\text { Ground yellow corn (IFN 4-03-005) } \\
\text { Tallow, bleachable fancy (IFN 4-07-880) } \\
\text { Soybean meal (IFN 5-04-612) } \\
\text { Beet pulp (IFN 4-00-669) } \\
\text { Dicalcium phosphate (IFN 6-01-080) } \\
\text { Calcium carbonate (IFN 6-01-069) } \\
\text { Monosodium phosphate } \\
\text { Sodium chloride, iodized } \\
\text { Trace mineral premixa } \\
\text { Vitamin premix b }\end{array}$ & $\begin{array}{r}69.82 \\
\ldots \\
15.47 \\
10.00 \\
2.67 \\
.38 \\
.08 \\
.50 \\
.08 \\
1.00 \\
100.00\end{array}$ & $\begin{array}{r}59.83 \\
8.00 \\
17.53 \\
10.00 \\
2.76 \\
.30 \\
\ldots . \\
.50 \\
.08 \\
1.00 \\
100.00\end{array}$ \\
\hline $\begin{array}{l}\text { Gestation intake, } \mathrm{kg} / \mathrm{day} \\
\text { Diet } \\
\text { Cornstarch } \\
\text { ME, kcal/dayc }\end{array}$ & $\begin{array}{r}1.82 \\
6,240^{.18}\end{array}$ & $\begin{array}{c}1.82 \\
6,240\end{array}$ \\
\hline
\end{tabular}

${ }^{2}$ Contributed the following in milligrams/kilogram of diet: $\mathrm{Zn}, 160 ; \mathrm{Fe}, 80 ; \mathrm{Mn}, 44 ; \mathrm{Cu}, 8 ; \mathrm{Co}, 8 ; 1,1.2$.

${ }^{b}$ Contributed the following per kilogram of diet: vitamin A, 5,500 USP; vitamin $D_{3}, 440$ ICU; vitamin E, 22 IU; riboflavin, $2.9 \mathrm{mg}$; pantothenic acid, $22 \mathrm{mg}$; niacin, $22 \mathrm{mg}$; choline chloride, $770 \mathrm{mg}$; vitamin $\mathrm{B}_{12}, 22 \mu \mathrm{g}$; menadione sodium bisulfite, $2.2 \mathrm{mg}$; ethoxyquin, $4.4 \mathrm{mg}$, in a ground corn carrier:

calculated. 
control group was fed daily $1.82 \mathrm{~kg}$ of a cornsoybean meal-based diet plus an additional ,18 $\mathrm{kg}$ of cornstarch. Their counterparts were fed $1.82 \mathrm{~kg}$ of a similar diet containing $8 \%$ bleachable fancy tallow $w^{5}$. The dietary regimens were designed to provide equal nutrient and energy intakes, so that supplemental source of energy was the variable of interest. The daily metabolizable energy intake per sow was calculated to be approximately 6,240 kilocalories. After parturition, sows were fed ad libitum for 24 hours.

Four pigs in each litter were subjected to a 48 -hr fast, which was initiated either at birth $\left(t_{0}\right)$ or after $24 \mathrm{hr}$ of access to the sow $\left(t_{24}\right)$. Pigs used in the to component of the study were obtained during farrowing, and a blood sample was collected from each immediately after birth. Each pig was removed to a clean, dry shelter with supplemental heat provided until parturition was complete. Subsequently, two pigs of each sex were selected for fasting. Separate litters were used in the $t_{24}$ group to ensure greater within-litter competition. The size of each litter was standardized to 10 pigs, with each sow having at least one additional functioning mammary gland. Pigs selected for fasting were placed in an environmentally controlled room $(27 \pm 1 \mathrm{C})$, weighed and individually housed in wire cages with ad libitum access to water. Supplemental heat was provided by infrared heaters positioned at the back of the cage.

Blood samples (approximately $3 \mathrm{ml}$ ) were obtained via the anterior vena cava (Carle and Dewhirst, 1942) with a 22-gauge needle at 0 , $12,24,36$ and $48 \mathrm{hr}$ after the start of the fast. Blood for glucose analysis was collected into a separate evacuated glass tube ${ }^{6}$ containing sodium fluoride to inhibit glycolysis and potassium oxalate as an anticoagulant. Blood for FFA and UN analyses was collected into an evacuated glass tube containing sodium heparin and chilled on ice until centrifuged. After centrifugation, the plasma was transferred to sterile plastic tubes and frozen $(-10 \mathrm{C})$ until analyzed. Plasma glucose was determined by the glucostat method ${ }^{7}$, FFA by a modification of the

\footnotetext{
${ }^{5}$ Bleachable fancy tallow, National By-Products, Bellevue, NE.

${ }^{6}$ Vacutainer tube, Becton-Dickinson, Rutherford, N].

${ }^{7}$ Sigma Chemical Co., St. Louis, MO.
}

semi-automated fluorimetric method of Carruthers and Young (1973) and UN by the automated method described by Kessler (1970). So that there would be enough sample for UN analysis, samples were pooled by combining equal proportions of plasma (sex within litter) within an hourly measurement.

Milk composition data were obtained for $\mathrm{t}_{24}$ sows, because the pig's metabolic response to fasting could have been the result of, or influenced by, the quality of colostrum consumed. Average composition was assessed by analysis of 50 - to $75-\mathrm{ml}$ samples of colostrum manually expressed from four to six glands at 0,12 and $24 \mathrm{hr}$ after the birth of the first pig. Milk release was induced by the injection of 60 IU of oxytocin IM. Samples of colostrum were stored at $-10 \mathrm{C}$ until analyzed. Total solids and fat content were determined according to AOAC (1975) procedures. The procedure used for determining milk fat content was the Babcock method.

Plasma metabolite data were analyzed statistically by an appropriate application of least-squares analysis of variance procedures for the split-plot design (Steel and Torrie, 1960; Snedecor and Cochran, 1967). The sow was defined as the experimental unit since sows were randomly allotted to treatment. The effect of time was evaluated by response surface analysis (linear, quadratic and cubic) for equally spaced intervals according to procedures outlined by Snedecor and Cochran (1967). Milk composition data were analyzed by analysis of variance procedures for the splitplot design. All analyses were accomplished by methods from the Statistical Analysis System (Barr et al., 1976).

Exp. 2. The progeny of 12 sows were sacrificed to provide additional information about the effect of maternal dietary energy source during gestation on liver glycogen and carcass lipid in pigs at birth. Dietary regimens and breed composition were the same as in Exp. 1. Three pigs per litter (mixed sexes) were removed immediately after birth, weighed, mechanically stunned and killed by exsanguination. As rapidly as possible, the liver was removed, blotted for the removal of blood, weighed and frozen in liquid $N$. The head, gastrointestinal tract and bladder were removed, and the carcass frozen in liquid $N$. The livers and carcasses were stored at $-10 \mathrm{C}$ until analyzed.

A common lobe was excised from each of the livers, homogenized in a tissue homogen- 


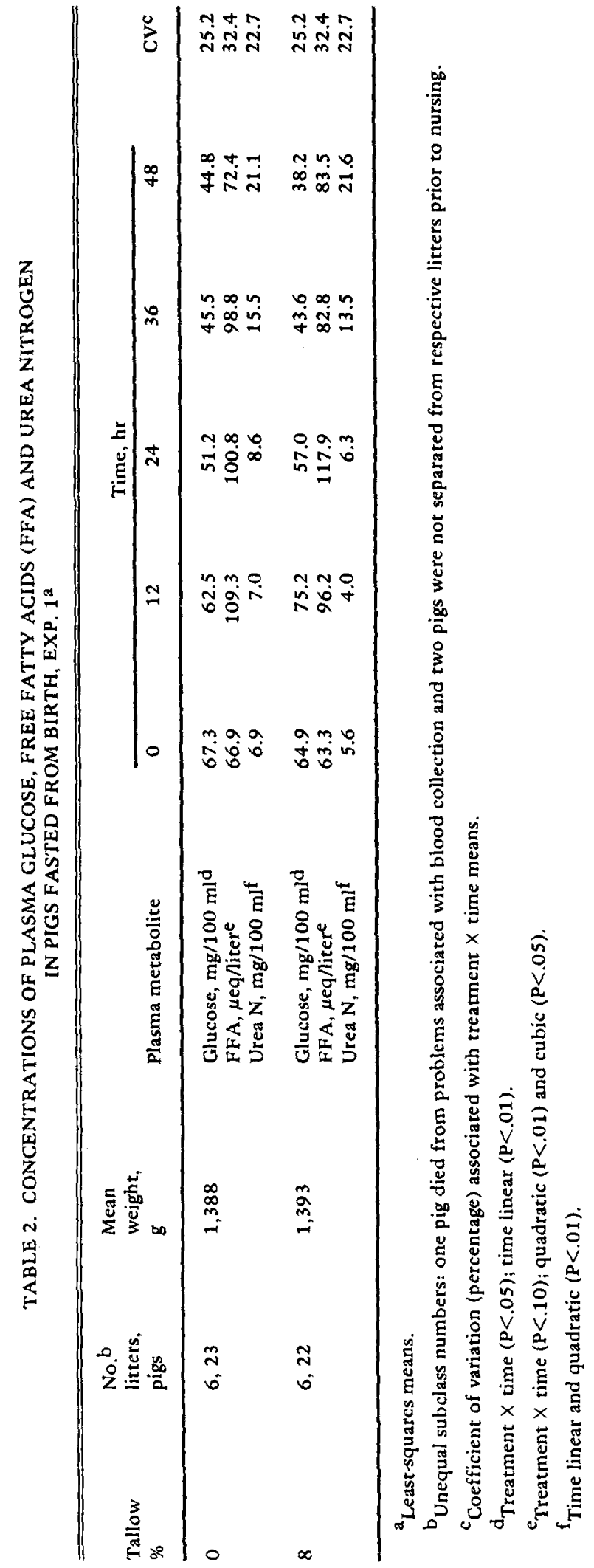


izer $^{8}$ (chilled on ice) and immediately subsampled for glycogen determination by the colorimetric micro-method of Kemp and Kits van Heijningen (1954). The frozen carcasses were passed twice through a meat grinder and then placed in a blender for homogenization prior to sampling for analysis. Samples of the homogenate were analyzed for total lipid content by the method of Folch et al. (1957). Moisture content of the ground carcass was determined by drying 3 to $4 \mathrm{~g}$ of the tissue at $105 \mathrm{C}$ for 24 hours.

Tissue data were analyzed by an appropriate application of least-squares analysis of variance procedures for the split-plot design, and statistical analysis was conducted according to procedures of the Statistical Analysis System (Barr et al., 1976).

\section{Results and Discussion}

Data presented in table 2 summarize the effects of maternal diet on the concentrations of glucose, FFA and UN in plasma of pigs fasted from birth. Glucose concentration at birth was similar for the two treatment groups and averaged approximately $66 \mathrm{mg} / 100 \mathrm{ml}$. The mean glucose concentrations, averaged across time, were 54.3 and $55.8 \mathrm{mg} / 100 \mathrm{ml}$ of plasma for control and tallow pigs, respectively, and were not different ( $P>.05$ ). However, pigs whose dams had been fed tallow during late gestation responded differently to the imposed fast than their control counterparts (treatment $x$ time, $P<.05)$. Pigs in the tallow treatment group had a mean glucose concentration of approximately $75 \mathrm{mg} / 100 \mathrm{ml}$ plasma at $12 \mathrm{hr}$, compared to $65 \mathrm{mg} / 100 \mathrm{ml}$ at birth. In contrast, the mean glucose concentration for the control group declined from approximately 67 $\mathrm{mg} / 100 \mathrm{ml}$ at birth to $62 \mathrm{mg} / 100 \mathrm{ml}$ by 12 hours. Pigs in the tallow treatment group maintained a slightly higher plasma glucose concentration during the initial $24 \mathrm{hr}$, but there was no difference between groups after that point. Glucose concentrations of pigs in both treatment groups declined (time linear, $\mathrm{P}<.01$ ) to approximately $44 \mathrm{mg} / 100 \mathrm{ml}$ by 36 hours. Thereafter, concentrations appeared to decline at a less rapid rate.

\footnotetext{
CO.

${ }^{8}$ Potter-Elvehjem, Fisher Scientific, Englewood,
}

Plasma FFA concentrations at birth and mean concentrations for the fast period were similar for the two treatment groups, averaging approximately 65 and $89 \mu \mathrm{eq} / \mathrm{liter}$, respectively. As in the case of glucose, there was a difference between the two treatment groups in FFA patterns during the fast (treatment $x$ time, $\mathrm{P}<.10$ ). Within the range of the data, pigs in the control treatment group attained a maximum FFA concentration by $12 \mathrm{hr}$, commensurate with a decline in glucose concentration. In contrast, pigs in the tallow group reached a peak concentration by $24 \mathrm{hr}$, which also paralleled a decline in glucose. In spite of decreasing glucose concentrations, the higher concentrations of FFA at 12 or $24 \mathrm{hr}$ were not sustained for the duration of the fast. This is characteristic of the newborn pig (Swiatek et al., 1968, Gentz et al., 1970). The quadratic $(\mathrm{P}<.01)$ nature of the plasma FFA pattern corresponds well with the suggestion of FFA mobilization initially, followed by failure to sustain lipolysis, when pigs are fasted during the initial hours after birth (Swiatek et al., 1968). The difference in FFA pattern between the two treatment groups may have been due to the different patterns of glucose concentration and, thus, "moment" of FFA mobilization. The basis for this is the well-known interrelationship between glucose and FFA in the fed and fasting animal.

Plasma UN concentrations at birth were 6.9 and $5.6 \mathrm{mg} / 100 \mathrm{ml}$ for control and tallow groups, respectively. UN concentration increased (time linear and quadratic, $P<.01$ ) during the fast, and, by $48 \mathrm{hr}$, the concentration for each group averaged approximately 21 $\mathrm{mg} / 100 \mathrm{ml}$. The mean UN concentration for the fasting period was 11.8 and $10.2 \mathrm{mg} / 100 \mathrm{ml}$ for the control and tallow pigs, respectively. No significant treatment or treatment $x$ time effects were observed. UN concentration appeared to be relatively stable during the initial $24 \mathrm{hr}$ but increased sharply thereafter, commensurate with declining FFA concentrations. Presumably, the increased UN concentration was indicative of a greater contribution by amino acids to the energy supply. Amino acids could make a significant contribution to the energetic status of the fasting pig through gluconeogenic and oxidative processes (Bayley et al., 1976).

The concentrations of glucose, FFA and UN in the plasma of pigs allowed to nurse $(24 \mathrm{hr})$ before fasting are presented in table 3 . Period means for glucose, FFA and UN $(70.3 \mathrm{ml} / 100$ 


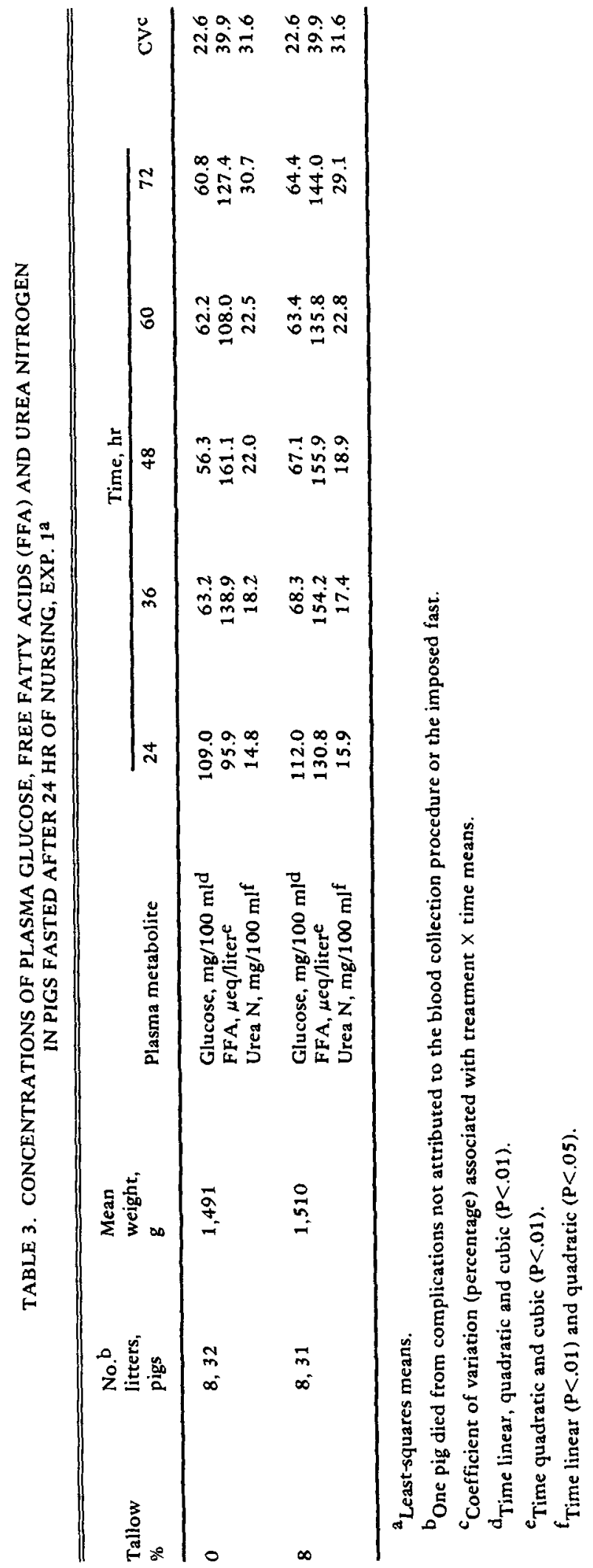


TABLE 4. EFFECT OF DIETARY TREATMENT ON TOTAL SOLIDS AND FAT CONTENT OF COLOSTRUM, EXP. 1

\begin{tabular}{|c|c|c|c|c|c|c|c|}
\hline \multirow{2}{*}{$\begin{array}{l}\text { Tallow } \\
\%\end{array}$} & \multirow{2}{*}{$\begin{array}{l}\text { No. } \\
\text { sows }\end{array}$} & \multirow[b]{2}{*}{ Component } & \multicolumn{4}{|c|}{ Hour of collection } & \multirow[b]{2}{*}{$C V^{a}$} \\
\hline & & & 0 & 12 & 24 & Period & \\
\hline 0 & 6 & $\begin{array}{l}\text { Solids, \%bc } \\
\text { Fat, \%bd }\end{array}$ & $\begin{array}{r}22.7 \\
9.6\end{array}$ & $\begin{array}{r}19.3 \\
9.6\end{array}$ & $\begin{array}{l}17.9 \\
11.3\end{array}$ & $\begin{array}{l}20.0 \\
10.1\end{array}$ & $\begin{array}{l}15.1 \\
19.7\end{array}$ \\
\hline 8 & 6 & $\begin{array}{l}\text { Solids, \%bc } \\
\text { Fat, \%bd }\end{array}$ & $\begin{array}{l}26.1 \\
12.3\end{array}$ & $\begin{array}{l}21.0 \\
11.3\end{array}$ & $\begin{array}{l}24.9 \\
16.2\end{array}$ & $\begin{array}{l}24.9 \\
13.4\end{array}$ & $\begin{array}{l}15.1 \\
19.7\end{array}$ \\
\hline
\end{tabular}

\footnotetext{
${ }^{a}$ Coefficient of variation (percentage) was calculated from the sow within treatment mean squares.

$b_{\text {Treatment }}(\mathrm{P}<.01)$.

$\mathrm{c}_{\text {Treatment }} \times$ time $(\mathrm{P}<.05)$.

$\mathrm{d}_{\text {Time linear }}(P<.01)$ and quadratic $(P<.05)$.
}

$\mathrm{ml}, 126 \mu \mathrm{eq} / \mathrm{liter}$ and $21.6 \mathrm{mg} / 100 \mathrm{ml}$, respectively, for the control group, and $75.0 \mathrm{ml} / 100$ $\mathrm{ml}, 144 \mu \mathrm{eq} / \mathrm{liter}$ and $20.8 \mathrm{mg} / 100 \mathrm{ml}$ for the tallow group. The plasma glucose concentration at $24 \mathrm{hr}$ was similar for both treatment groups (approximately $110 \mathrm{mg} / 100 \mathrm{ml}$ ). After the initial decline in glucose concentration $(24$ to $36 \mathrm{hr}$ ), the pigs maintained a relatively stable fasting level. During the initial $24 \mathrm{hr}$ of fasting, pigs in the tallow treatment group maintained a slightly higher glucose concentration than the controls $(12 \mathrm{hr}-68.3$ vs $63.2 \mathrm{mg} / 100 \mathrm{ml} ; 24$ $\mathrm{hr}-67.1$ vs $56.3 \mathrm{mg} / 100 \mathrm{ml}$ ); however, no significant treatment effect or treatment $x$ time interaction was observed.

Pigs in the tallow treatment group had a higher, though not significantly different, mean plasma FFA concentration during the fast than pigs in the control group (144 vs 126 $\mu e q /$ liter). In both groups, FFA reached maximal concentrations by $48 \mathrm{hr}$ and declined thereafter (time quadratic $\mathbf{P}<.01$ ). Concurrent with declining FFA concentration was an increase in UN (rime linear and quadratic, $P<.05$ ). As with the pigs fasted from birth, the increase in UN concentration was more pronounced with prolonged fasting and declining FFA.

The response of pigs allowed to nurse for $24 \mathrm{hr}$ and then fasted may have been influenced by the composition and quantity of colostrum acquired. Sows fed tallow during lare gestation had a higher $(\mathrm{P}<.01)$ concentration of colostrum solids and fat (table 4) during the initial $24 \mathrm{hr}$ than did sows fed the control diet $(24.9 \%, 13.4 \%$ vs $20.0 \%, 10.1 \%$, respectively). Perrin (1955) reported that the total solid frac- tion of colostrum was highest at the start of parturition and decreased during nursing. The rate of decline in total solids was different (treatment $\times$ time, $\mathrm{P}<.05$ ) for sows in the two treatment groups. Sows in the tallow group had a higher concentration of solids at $24 \mathrm{hr}$ $(24.9 \%)$ relative to the onset of parturition (26.1\%) than did sows fed the control diet (17.9 vs $22.7 \%$ ). The fat content increased (linear and quadratic, $\mathrm{P}<.05$ ) during the initial 24 $\mathrm{hr}$ in both groups. Similar increases in the fat content of colostrum of sows receiving a lipid source during gestation have been reported by other workers (Seerley et al., 1974, 1978a; Cast et al., 1977; Okai et al., 1977; Boyd et al., $1978 \mathrm{~b})$. The net effect of giving sows a lipid source would be to increase the energy density of colostrum (Seerley et al., 1978b).

The fact that the colostrum of sows on the tallow regimen contained more fat than that of control sows presumably accounts for the higher levels of plasma FFA in the offspring at $24 \mathrm{hr}$ (table 3) and the slightly higher level maintained throughout the fast. Thus, the metabolic response to fasting among pigs in the tallow group was enhanced but not markedly different from that of pigs in the control group. The quality of the milk may be of greater importance to smaller pigs, which compete less effectively with littermates for regular nourishment from the dam (Hartsock et al., 1977). Boyd et al. (1978a) reported that the addition of tallow to the diet of gestating-lactating sows markedly enhanced plasma glucose concentration during the initial $24 \mathrm{hr}$ in smaller, less competitive nursing pigs (680 to $1,090 \mathrm{~g}$ ). 
TABLE 5. EFFECT OF DIETARY TREATMENT ON CARCASS LIPID AND LIVER GLYCOGEN IN THE NEWBORN PIG, EXP. $2^{2}$

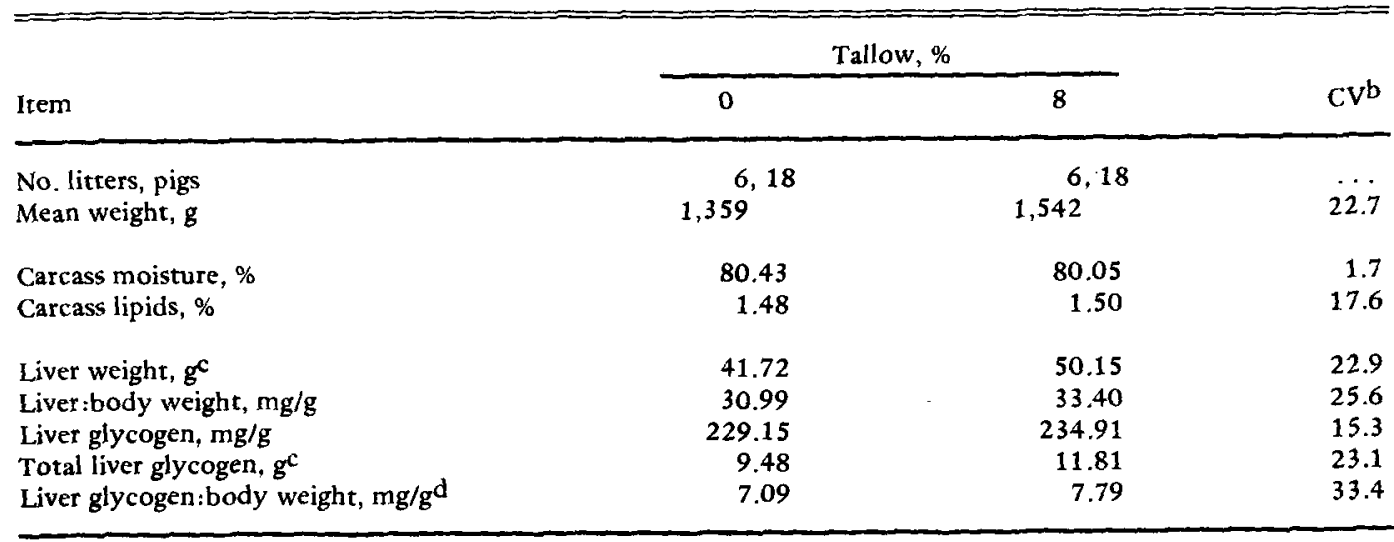

\footnotetext{
${ }^{\mathrm{a}}$ Least-squares means.

${ }^{b}$ Coefficient of variation (percentage) was calculated from litter within treatment mean squares.

cTreatment $(\mathbf{P}<.05)$.

$\mathrm{d}_{\text {Partial correlation coefficient }}=-.12$ between body weight and liver glycogen to body weight ratio.
}

The effect of maternal dietary energy source during late gestation on carcass lipid and liver glycogen in progeny was evaluated and the data are presented in table 5. Newborn pigs in both groups were similar in carcass composition. Pigs in the control group had $1.48 \%$ carcass lipid and approximately $229 \mathrm{mg}$ glycogen/g wet liver tissue, compared to $1.50 \%$ and $235 \mathrm{mg} / \mathrm{g}$ for pigs in the tallow group. The liver glycogen to body weight ratio, however, was 7.1 and 7.8 $\mathrm{mg}: \mathrm{g}$ for the control and tallow groups, respectively. This difference was not statistically significant.

The liver glycogen data are consistent with results from earlier studies (Seerley et al., 1974; Boyd et al., 1978a; Okai et al., 1978) in which no significant increases in liver glycogen were observed. The fasting data $\left(t_{0}\right)$ demonstrate, however, that the energetic status of the fasting newborn pigs was enhanced slightly when the sows' diet contained tallow. This provides some basis for the small increase observed in liver glycogen content of piglets whose dams received tallow in this and a previous experiment (Boyd et al., 1978a). Even though glucose homeostasis was improved in pigs in the tallow treatment group, the increase was small. Lack of an increase in plasma FFA $\left(t_{0}\right)$ is supported by the carcass lipid data.

More information is needed about the mechanisms controlling nutrient partitioning be- tween the sow and fetus if fetal energy storage is to be increased. Ezekwe and Martin (1978) have demonstrated the ability of the fetus to respond by increasing liver glycogen storage twofold when the appropriate maternal stimulus is provided (i.e., increased maternal glucose availability). The result of increased energy acquisition in utero would be decreased susceptibility to development of hypoglycemia postnatally, which would be particularly important to smaller, less competitive pigs in the litter. This would improve the baby pig's chances for survival and improve sow productivity.

\section{Literature Cited}

Anderson, R. H. and R. C. Wahlstrom. 1970. Effects of energy intake and dichlorovos during gestation on reproductive performance of gilts and some chemical characteristics of the offspring. J. Anim. Sci. $31: 907$.

AOAC. 1975. Official Methods of Analysis (12th Ed.). Association of Official Analytical Chemists, Washington, DC.

Barr, A. J., J. H. Goodnight, J. P. Sall and J. T. Helwig. 1976. A User's Guide to SAS 76. SAS Institute Inc., Raleigh, NC.

Bayley, H. S., J. L. Atkinson, M. J. Newport and E. R. Chavez. 1976. Amino acid metabolism in the fasting piglet. P. 105-108. In M. Vermorel (Ed.) Energy Metabolism of Farm Animals. Proc. Seventh Symposium, European Assoc. Anim. Prod., No. 19, Vichy, France.

Bengtsson, S. G. 1970. Serum nitrogenous compounds 
in piglets during the early postnatal period. J. Anim. Sci. $31: 531$.

Boyd, R. D., B. D. Moser, E. R. Peo, Jr. and P. J. Cunningham. 1978a. Effect of energy source prior to parturition and during lactation on tissue lipid, liver glycogen and plasma levels of some metabolites in the newborn pig. J. Anim. Sci. 47:874.

Boyd, R. D., B. D. Moser, E, R. Peo, Jr. and P. J. Cunningham. $1978 \mathrm{~b}$. Effect of energy source prior to parturition and during lactation on piglet survival and growth and on milk lipids. J. Anim. Sci. 47:883.

Carle, B. N. and W. H. Dewhirst, Jr. 1942. A method for bleeding swine. J. Amer. Vet. Med. Assoc. $101: 495$.

Carruthers, M. and D.A.B. Young. 1973. Free fatty acid estimation by a semi-automated fluorimetric method. Clin. Chim. Acta 49:341.

Cast, W. R., B. D. Moser, E. R. Peo, Jr. and P. J. Cunningham. 1977. Fat, choline and thyroprotein additions to the diet of lactating swine. J. Anim. Sci. 45 (Suppl. 1):80.

Elliott, J. I. and G. A. Lodge, 1977. Body composition and glycogen reserves in the neonatal pig during the first 96 hours postpartum. Can. J. Anim. Sci. 57:141.

Ezekwe, M. O. and R. J. Martin. 1978. Influence of maternal alloxan diabetes or insulin injections on fetal glycogen reserves, muscle and liver development of pigs (Sus domesticus). J. Anim, Sci. 47: 1121.

Folch, J., M. Lees and G. H. Sloane Stanley. 1957. A simple method for the isolation and purification of total lipides from animal tissue. J. Biol. Chem. 226:497.

Friend, D. W. 1974. Effect on the performance of pigs from birth to market weight of adding fat to the lactation diet of their dams. J. Anim. Sci. 39: 1073.

Gentz, J., G. Bengtsson, J. Hakkarainen, R. Hellstrom and B. Persson. 1970. Metabolic effects of starvation during neonatal period in the piglet. Amer. J. Physiol. 218:662.

Graham, R., J. Sampson and H. R. Hester. 1941. I. Acute hypoglycernia in newly born pigs (socalled baby pig disease). Proc. Soc. Exp. Biol. Med. 47:338.

Hakkarainen, J. 1975. Developmental changes of protein, RNA, DNA, lipid and glycogen in the liver, skeletal muscle and brain of the piglet. Acta Vet. Scand. Suppl. 59:1.

Hartsock, T. G., H. B. Graves and B. R. Baumgardt. 1977. Agonistic behavior and the nursing order in suckling piglets: Relationships with survival, growth and body composition. J. Anim. Sci. 44:
320.

Kemp, A. and A.J.M. Kits van Heijningen. 1954. A colorimetric micro-method for the determination of glycogen in tissue. Biochem. $J$. $56: 646$

Kessler, G. 1970. An automated system of analysis. P. 340-42. In S. Frankel, S. Reitman and A. C. Sonnenwirth (Ed.) Gradwohl's Clinical Laboratory Methods and Diagnosis (7th Ed.). C. V. Mosby Co., St. Louis, MO.

Mersmann, H. J. 1971. Glycolytic and gluconeogenic enzyme levels in pre- and postnatal pigs. Amer. J. Physiol. 220:1297.

Mersmann, H. J. 1974. Metabolic patterns in the neonatal swine. J. Anim. Sci. 38:1022.

Okai, D. B., F. X. Aherne and R. T. Hardin. 1977. Effects of sow nutrition in late gestation on the body composition and survival of the neonatal pig. Can. J. Anim. Sci. 57:439.

Okaj, D. B., D. Wyllie, F. X. Aherne and R. C. Ewan. 1978. Glycogen reserves in the fetal and newborn pig. J. Anim. Sci. 46:391.

Perrin, D. R. 1955. The chemical composition of the colostrum and milk of the sow. J. Dairy Res. 22: 103.

Sampson, J., H. R. Hester and R. Graham. 1942. Studies on baby pig mortality. II. Further observations on acute hypoglycemia in newly born pigs (so-called baby pig disease). J. Amer. Vet. Med. Assoc, 100:33.

Seerley, R. W., F. M. Griffin and H. C. McCampbell. 1978a. Effect of sow's dietary energy source on sow's milk and piglet carcass composition. J. Anim. Sci. 46:1009.

Seerley, R. W., J. S. Maxwell and H. C. McCampbell. $1978 \mathrm{~b}$. A comparison of energy sources for sows and subsequent effect on piglets. J. Anim. Sci. 47:1114.

Seerley, R. W., T. A. Pace, C. W. Foley and R. D. Scarth. 1974. Effect of energy intake prior to parturition on milk lipids and survival rate, thermostability and carcass composition of piglets. J. Anim. Sci. 38:64.

Snedecor, G. W. and W. G. Cochran. 1967. Statistical Methods (6th Ed.). The Iowa State Univ. Press, Ames.

Steel, R.G.D. and J. H. Torrie. 1960. Principles and Procedures of Statistics. McGraw-Hill Book Co., New York.

Swiatek, K. R. 1971. Development of gluconeogenesis in pig liver slices. Biochim. Biophys. Acta 252 : 274.

Swiatek, K. R., D. M. Kipnis, G. Mason, K. L. Chao and M. Cornblath. 1968. Starvation hypoglycemia in newborn pigs. Amer. J. Physiol. 214: 400 . 